\title{
THE LOCATION OF NEW KINGDOM ELITE TOMBS - SPACE, PLACE AND SIGNIFICANCE ${ }^{1}$
}

\begin{abstract}
This paper deals with the significance of provincial New Kingdom elite tomb location. It aims to describe a key element of the relationship between the elite and the spatial distribution of their archaeological evidence in terms of 'territoriality'. It focuses especially on the tomb, the pivotal component of the elite's monumental display. A unique perspective is adopted, derived from both the sociology of space and cultural anthropology. The theoretical background of 'territoriality' and its wide range of applications are outlined firstly with a short review of key definitions. The paper's focus then shifts to the domain offunerary archaeology by examining the location of tombs and its significance. The factors affecting location are discussed from a prosopographical perspective and contrasted with statements from so-called (auto-)biographical self-presentations. Both inscriptional and prosopographical data is the key to understand the underlying considerations for tomb location.

\footnotetext{
1 This paper is based on my PhD-dissertation, Die Territorialität der Ägyptischen Elite(n) des Neuen Reiches, supervised by Prof. Dr. Stephan J. Seidlmayer and funded by the Berlin Cluster of Excellence TOPOI - The Formation and Transformation of Space and Knowledge in Ancient Civilizations. I wish to thank both for their scientific and financial support respectively. I also want to thank the organizers of the conference, Mariusz A. Jucha, Joanna Dębowska-Ludwin and Piotr Kołodziejczyk, for giving me the opportunity to put these thoughts up for discussion in Krakow. Lastly, I owe special thanks to Maarten Horn, Mat Dalton and the editors for checking my English and many useful comments and suggestions. The paper represents research in 2012, no further bibliographical additions or contentual emendations have been made since its initial writing.
} 
Keywords: Territoriality; space and identity; (auto-)biographical texts; New Kingdom elite prosopography; home and geographical provenance; proximity to the king; administrative relationships

\section{Introduction: starting points and issues}

A wide-ranging Egyptological discussion exists about necropoleis of the New Kingdom and their internal topographical and distributional structure. This discussion also concerns the cultural meaning of necropolis structures and their sociological interpretation. This issue applies to the large and well-known necropoleis of the royal and capital cities Thebes, Memphis and Tell el-Amarna (e.g. Engelmann-von Carnap 1995; Engelmann-von Carnap 1999; Raven 2000; Arp 2012), as well as to those of a more provincial character (e.g. Wada 2007; for a summary of both see Richards 2005, 6974 , with literature). The architectural size and the layout of single tombs, their funerary furniture and their location in relation to other sepulchres can be taken into account to describe the social status of their owners. Tombs are therefore considered by scholars to be significant monuments that give us an idea of the composition of ancient Egyptian society (cf. Dodson and Ikram 2008, 23-30).

The present paper aims to highlight a phenomenon discussed in Egyptology, that has, however, not yet received the attention it warrants. It concerns the ideological significance of the location chosen for New Kingdom elite tombs. In this respect, cemeteries belonging to large royal and capital cities are just as telling as provincial cemeteries such as Sedment, El-Khawaled, Asyut, El-Mashayikh, Zawyet Sultan and Er-Rizeiqat, to name but a few. The question underlying this investigation in both contexts concerns what kind of spatial and social relations were indicated by a tomb's location. As this inquiry will be dealt with using the concept of 'territoriality', issues pertaining to social origin and geographical provenance, as well as functional duties and the local social embeddedness of the tomb owners come to mind.

Are Egyptian elite tombs and their location useful in gaining an insight into the spatial origins of its owners? The provincial tomb of a member of the courtly elite located in one of the aforementioned provincial burial grounds might serve as a direct territorial marker indicating the geographical origin of its owner. Wolfram Grajetzki $(2003,89)$ therefore asks in this context: '[W]hy were these officials buried in these particular places?' and gives the immediate answer, that 'the easiest explanation' is that they were 
all buried where they were born. This situation should not merely be considered as 'the easiest explanation'. In fact, it should be regarded as the only feasible one, as we will see in the following paragraphs.

\section{Setting the terms: territoriality}

As we will use 'territoriality' as the central explanatory concept, it is imperative that we make some brief definitions of the term as well as the approach used here available to the reader. The conceptual background of the term was primarily established by ethologists studying animal behaviour (cf. Burt 1943; Martin 1972; Malmberg 1980, 27-53) and was then adopted by ethnologists, cultural anthropologists and sociologists, who each adjusted it to their own particular scientific perspectives (cf. Carpenter 1961; Lyman and Scott 1967; Dyson-Hudson and Smith 1978; Cashdan 1983). Some of these scholars understood territoriality as an instinctual routine and adapted it to the human sphere by stating (from a now refuted biologistic perspective on territorial behaviour) that ' $[t]$ he study of human territoriality is the study of human behaviour' (Scheflen and Ashcraft 1976, 4). A more recent and comprehensive examination of territoriality is provided by Robert D. Sack (1983, 55; see also 1986). He especially takes the cultural embeddedness of human behaviour into account: 'Human Territoriality is a means of affecting (enhancing or impeding) interaction and extends the particulars of action by contact. Territoriality is defined [...] as the attempt to affect, influence, or control actions, interactions, or access by asserting and attempting to enforce control over a specific geographic area'. This quote demonstrates a general scholarly tendency to focus on the term's aspect of control of geographic space, which is also employed in the most widespread use of 'territoriality' in politics. In this sense, it describes the territorial behaviour of states in terms of control and defence of their national territory and its people (cf. Forsberg 1996; Agnew 2005; Vollard 2009).

Other definitions focus more on the psychological aspects of territoriality and try to describe actual or imagined relationships between people and space. This is what psychologists call the "emotional agenda" of territoriality' (Albert 2001, 6). Territoriality as 'an extremely widespread phenomenon [...] operative in our largest-scale endeavours, war and global trade, as well as in many of our smallest, such as claiming our seats at the dinner table' (Gifford 1997, 136) is also defined as 'a self/other boundary regulation mechanism that involves personalization of or marking 
of a place or object and communication that it is "owned" by a person or group. Personalisation and ownership are designed to regulate social interaction and help satisfy various social and physical motives' (Altmann 1975, 107). In this functionalistic approach, the matter of individual ownership of socially appropriated (i.e. territorialised) places and objects as well as the personalisation of space to satisfy social and physical needs are central.

Territoriality is also discussed within the psychoanalytical paradigm as a 'perspective on unconscious individual and social processes', that provides 'important explanatory aspects for the perception of the spatial environment, but also for the spatial and geographical behaviour of human groups' (transl. by the author from Jüngst 2000, 14). The 'emotional agenda' of territoriality comes also into play for the development of personal and collective identities. Since the psychological attachment of people to space(s) and places differs significantly within cultures, the biologistic approach can be challenged by the fact that 'the role of territoriality in defining collective identities is not a natural given and that it can change' (Albert 2001, 6). Territoriality only becomes a feature of identity when territory and space are perceived as emic cultural codes to generate identity. From this perspective, territoriality can thus be described as a 'major anchor of identity' (Forsberg 1996, 361-362).

Territoriality is also used as a conceptual framework to focus on the relationship between space and human behaviour by Egyptologists, who generally understand it in its broadest political sense. Michael Hoffman $(1980,325)$, for instance, discusses the political territoriality of the early state and the definition of its borders, whilst Silvia Lupo (2007a; 2007b) focuses on the territorial strategy of the Old Kingdom state in establishing pyramid towns and royal necropoleis to appropriate geographic space. In a recent presentation at the Current Research in Egyptology conference in Birmingham, Marina Wilding Brown (CRE 13, Abstracts, 8-9) also used the term when referring to ancient Egyptian graffiti that served as markers of territorial demarcation. However, for the purpose of this paper it is necessary to move the focus of the term away from the political aspects of territorial control towards the concept of spatial identity, as expressed in individual territorial behaviour. This is essential for this paper, because the term will be used from a sociological and psychological perspective by focusing on individuals or groups of people and all the different kinds of spatial relationships they have or portray. Based on the relational conceptualisation of Claude Raffestin (1984), Francesco Klauser (2008, 7 ; 2010) describes territoriality as 'the whole myriad of conscious 
and unconscious engagements and interrelations between individual or collective social actors and space, which are present in the constitution of territorial claims, disputes and geographically anchored identities'. Territoriality can thus be understood as an analytical term used to describe many types of human relationships with space and spatial phenomena.

In the case of the New Kingdom elite, these relations are mediated or expressed by the different monuments that they erected. The following observations are therefore based on prosopographical and archaeological records of members of the New Kingdom elite. As far as the individual and prosopographical level of territoriality is concerned, we may identify five main conceptual dimensions, which together form a structure of mutually complementary aspects. As such, territoriality can be understood (at least for our understanding of the archaeological evidence of the Egyptian elite) as an anthropological category constituted by a matrix of the following five dimensions:

The 'archaeological-geographical dimension' refers to all the monuments of the elite distributed throughout Egypt and all its political spheres of influence. When focusing on the monuments of a single person (e.g. the Viceroy of Nubia Setau under Ramesses II), it is possible to describe his radius of action by mapping all his records and attestations (see Raedler 2003). The 'praxeological dimension' embeds those archeologically and geographically distributed records into contexts of activities and conduct. A rock inscription at Aswan can thus be seen as a marker of presence at a particular spot where specific tasks were undertaken or certain activities were participated in (see Seidlmayer 1999 and 2003). The 'sociological dimension' describes the social as well as functional differentiation of people in relation to each other and the effect of these relationships and functions on the range of travel and the activities performed by the elite. By way of example, the extremely mobile viziers may be contrasted with the comparatively stationary mayors of Egyptian towns. The Theban mayors under the Vizier P3-Sr (Sethi I-Ramesses II), whose own monumental displays range from Nubia to the Nile Delta (see Raedler 2004, 309-354, fig. 5), are only known from monuments in Thebes itself. ${ }^{2}$ The 'psychological-

\footnotetext{
2 The mayors of eastern Thebes were Jmn-m-h3b (TT A8: Manniche 1988, 47-49; Kruck 2012, 89-92), Nfr-mnw (TT 184: Kitchen 1980, 162,7-163,7; Fábián 1997; Fábián 2005), P3-Sr (Kitchen 1980, 157,12-161,3; mentioned in TT 183: Kitchen 1980, 182,11, 183,3 and 8, 185,2-3, 185,12; the funerary cone Nr. 161 [Davies and Macadam 1957, Nr. 161; KRI IV, 529,11] possibly belongs to him) and H3w-nfr (TT 385: Kitchen 1980, 163,8-164,5; mentioned in TT 183: Kitchen 1980, 183,10, 184,15-16); see also Jmn-ḥtp (Schneider 1977, 37, cat.-nos 3.1.1.9 and 3.1.1.10, figs 10 and 85). For the mayor of western Thebes $R^{\complement}-m s$
} 
cognitive' dimension represents the attitude of the Egyptians towards space and spatial entities and incorporates the parameters of the Egyptian perception of space portrayed by the previously mentioned dimensions, as well as the surviving textual records. Finally, the 'ideological dimension' or the 'dimension of cultural knowledge' interconnects socio-cultural facts with their reasons and motives in forming a comprehensive and meaningful framework for culturally appropriate behaviour in space.

\section{Space, place and significance: tomb location}

Following this theoretical introduction, we return to the question of the significance of elite tomb location. Tombs are of paramount archaeological and sociological importance. In Egyptology, they are actually labelled as defining monuments of the Egyptian civilisation (e.g. Dodson and Ikram 2008, 8). They constitute monuments which embody aspects of the five territorial dimensions in various ways. The tomb can be regarded as a communicative medium that displays status, wealth, identity, gender, personality, social and family relationships, as well as religious affiliation. This all comes with a good deal of conspicuous consumption epitomising the elite's striving for prestige (cf. Dodson and Ikram 2008; see also Richards 2005, 49-69). The tomb is also a social product of an individual or community, and, in what seems to have been an exclusively elite phenomenon, was planned and built during the lifetime of its owner. As regards its location, ideological considerations were taken into account that were neither random nor fortuitous, but rooted rather in culturally significant meaning.

According to Jan Assmann, the Egyptian tomb ultimately represents 'the crucial focus of belonging in Egypt' (transl. by the author from Assmann 2000, 229). What, therefore, can the location of a tomb tell us about its owner from a territorial perspective? What does the choice of a certain person to be buried at this or that necropolis imply? What factors of space and place led to this choice? All these questions do not refer to the significance of the tomb's location within a given necropolis, but instead to the location of the chosen necropolis itself in connection with the administrative function, social status and supposed geographic provenance of the tomb's owner.

As far as the Old and Middle Kingdoms are concerned, research has been undertaken on the location and distribution of elite rock-cut and mastaba tombs representing various metiers of the nationwide elite (cf. Fisher

see Kitchen 1980, 161,4-162,6, 160,8 and Kitchen 1979, 802,8. 
1954; Franke 1991, esp. 63-65; Kanawati 2004; Dodson and Ikram 2008, 27; Grajetzki 2009, 106-121, 152). In view of individual decisions versus the deliberate policy of the Egyptian state, i.e. the king, in choosing or assigning a spot for an official's tomb, a certain tension can be discerned between a location in the royal city and the provinces in most cases. This issue can generally be described as a friction between two opposing concepts. On the one hand, there is the social and functional proximity of the elite member to the ruling king, which is expressed by the geographic proximity of the tomb to the royal residence and/or the royal tomb. On the other hand, there is the social and functional relationship of the elite member with his own personal, official and local environment, which also finds an expression in tomb location. Naguib Kanawati states that 'officials usually built their tombs where they served', but that there was also the 'traditional desire of the Egyptian to be buried near other members of his family' (Kanawati 2004, 51). This is often described as a prevailing provincial phenomenon (Dodson and Ikram 2008, 27). In the case of officials serving at an administrative centre near the king whose families also resided in the residence or capital city, these two normally conflicting relationships coincide. In the case of New Kingdom functionaries of the royal court whose tombs were not situated at Thebes, Saqqara or Tell el-Amarna, other ideological considerations and relationships must have been taken into account.

Regarding the New Kingdom, investigations have been carried out with the aim of determining the nature of the Egyptian capital cities through prosopographical research based on the tomb owners of their necropoleis. Thebes has thus been classified as a sacerdotal centre, Amarna as a religious capital and Memphis as the administrative centre throughout the 18th dynasty until the founding of the Delta capital Pi-Ramesse (Martin 2000, 99-120). Geoffrey T. Martin $(2000,119)$ comments on the desire of the elite to be buried at Thebes by stating that the "presence of the New Kingdom royal cemeteries [...] was no doubt a powerful magnet for "the great and the good" of those days. Personal choice of a burial place must also have played a part'. Maarten J. Raven's $(2000,135)$ remarks on the history of the occupation of the Saqqara necropolis, its environs in the New Kingdom and the distribution of the tombs conclude with the following statement: 'All this shows that the vicinity of the royal residence was not the only factor for deciding the importance of the Saqqara necropolis'. Over the course of his study, he discusses several modi of associative patterns relating to these tombs and their owners. At Saqqara, mechanisms such as professional association, patterns of patronage, personal connections 
and dynastic considerations seem to have existed (Raven 2000, 136-138). Religious reasons for Saqqara's prominence are also advanced by scholars. They derived from socio-cultural fractures caused by the Amarna period that led in turn to an increase in the significance of the Memphite god PtahSokar-Osiris, who became the dominant figure of the funerary cult (van Dijk 1988, 40-44).

The individual territorial relationship between the tomb owner and his place of burial (as established and marked by the sepulchre itself) does not, however, seem to have been specifically considered in existing studies. Yet the sepulchre represents a part of the spatial identity of the tomb owner. Using Tell el-Amarna, a New Kingdom elite necropolis par excellence, as a contrastive set (cf. Davies 1903-1908), it can be noted that tomb location depended solely upon an individual's proximity to the king as well as upon associations with the administrative and religious apparatus. There are no implications of geographic provenance mirrored bytheAmarnatombs. Indeed, theonly aspectconsidered intheAmarna example is the prosopographical composition of a residence necropolis in a specific time period under specific ideological circumstances. However, it could be argued that Amarna represents a significant case that is, at least structurally, comparable to Saqqara. Amarna also mirrors the concept of Western Thebes as a royal and elite necropolis to a certain degree. The Amarna tomb owners were part of the highest social stratum of the city and were, to varying degrees, integral members of its court. Since all the sarcophagus chambers of the Amarna rock-cut elite tombs were left unfinished (Arp 2012, 155), it seems that no members of the elite of Akhet-Aten were actually buried there.

Nevertheless, the underlying factors prompting elite tomb construction in Amarna can be deduced. First of all, there was the functional relationship of the official with governmental activities and the court of Amarna. Other factors included the courtiers' social and spatial proximity to the ruler and his tomb, as well as their standing in the kings' favour (cf. Guksch 1994), plus the prospect that both the families of Akhet-Aten's elite and the newly founded city would continue to exist here for generations to come. The ruler was considered the main focal point of social standing and therefore the personal relationship of a member of the elite to the king defined their personal status to a large extent. This position was often displayed in the context of the gold of honor scene in the rock-cut tombs (Binder 2008). The favour of the king Akhenaten was therefore essential in earning the privilege of acquiring a tomb in the elite necropolis of Tell el-Amarna (Arp 2012, 139). 
As a contrast to the capital city of Amarna, we will now shortly focus on a more localised and/or provincial milieu to investigate a specific group with characteristic territoriality. The people in question are the so-called h3.tjw-e, 'mayors' or 'governors' of towns. The functional agenda of these mayors focused on their local milieu and territory; thus their sphere of activity was more or less restricted to their area of competence (cf. Helck 1958, 194-245). An analysis of the social provenance of h3.tjw-e known from the New Kingdom reveals that they tended to hail from the local and/or provincial milieu which they administered, and that they were also often descendants of former mayors (see Auenmüller, forthcoming, 731-740). However, most mayors of the capital cities and other important towns like Thinis did not have this social background. This could perhaps signify that a different recruitment policy was followed in these other important places.

The two aspects of spatial relations mentioned above, origin and functional duties, are in most cases demonstrated by the location of mayoral tombs in local elite necropoleis. In fact, almost three quarters of archaeologically verifiable mayoral tombs are situated in the elite cemetery of their city (see Auenmüller 2011,21-22). This is a noteworthy finding, since it underlines the significance of the tomb and its location as an essential and permanent expression of the spatial relation of a group of people to their place of office and/or origin. This is particularly evident in peripheral regions such as Nubia and the Bahariya oasis (for a New Kingdom mayor of Bahariya and his tomb see van Siclen III, 1981).

There are, however, exceptions to the rule (cf. Auenmüller 2011, 22-25). Some provincial mayors were buried in tombs within the Theban necropolis. ${ }^{3}$ However, a Theban tomb was not just limited to provincial

\footnotetext{
3 These are Sbk-htp B of Fayum (TT 63: Dziobek and Abdel Raziq 1990; A.II.-T. IV.); Mnt..w-hr-hnpš=f of Qau El-Kebir (TT 20: Davies 1913, 1-19, pls 1-19; T. III.); Jnj-jtj=f (TT 155: Säve-Söderbergh 1957, 11-21, pls 10-20; Hat./T. III.), Mnw (TT 109: Porter and Moss 1985, 226-227; T. III.) and Jmn-htp (TT A19: Manniche 1988, 52-53; A.II.-T. IV.) of Thinis, $S j$ of the 'Northern Oasis' (Bahariya) (TT NN in Dra Abu El-Naga: Kruck 2012, 126-127; Ushebti aus 'Qurna' CG 48119: Newberry 1957, 293-294; 18th Dynasty) and lastly Dhww.tj-ms of Esna (TT 32: Kákosy et al. 2004; Ra. II.). While Kákosy (et al. 2004, 355-356) interprets his mayoral title as honorific and describing a retirement position, Dhw.tj-ms is here included in the list. There are three other problematic cases: Björkmann $(1974,46-47)$ argues for TT 91 as the tomb of the mayor Nby of Sile (T. IV.), while Morris $(2005,174)$ considers his tomb to be at Tjaru (Tell Hebua) itself. The status of Sn-nfrj (TT 99: Strudwick 2000; T. III.) as mayor of Koptos or Letopolis is not clear due to the writing of the associated toponym (cf. Sethe 1906, 546,14-15). That he derives from a provincial family from the eastern Delta does, however, seem to be ascertainable
} 
officials either, since also mayors of the administrative capital Memphis were buried there. These are Kn-Jmn R3k3 (TT NN; T. III.) and $M n-h p r$ (TT -81-; A. III.) (Geßler-Löhr 1997, 34-36, 51-56). As the link between mayors and the elite necropoleis of their cities seems to have been a general trend in their funerary archaeology, the question arises as to why some were buried at Thebes.

Why did these people break the traditional bond between tomb and place of office or origin? One option to answer this question is to look at prosopographical data to determine whether these people or their parents originated in Thebes. If this were the case, the location of the tomb would mark their own geographical provenance. In this regard, the location of paternal tombs should also be taken into account as evidence. However, only the father of Mnw of Sbk-htp B, mayor of the Fayum, is known to have had a tomb that once existed in Thebes. It is only known thanks to a funerary cone (Davies and Macadam 1957, Nr. 499; Dziobek and Abdel Raziq 1990, 81-82). Another variable to be considered is the functional connection of these people to Theban institutions, temples, the king and the state, which can be discerned from some of their titles. Kn-Jmn R3k $3^{\prime}$ titles, for instance, suggest a connection to the cult of Amen, and Dhw.tj$m s$ from Esna was High Stewart of Amen-Ra at Thebes (see Auenmüller 2011, 23, tab. 1). By reviewing the available evidence, most external mayors with tombs in Thebes who also have known parentage, with the possible exception of Nby of Sile (cf. Björkman 1975, 43-51) and the two mayors of Memphis Kn-Jmn Rzk3 and Mn-hpr (cf. Geßler-Löhr 1997, 34-35, 5156), can be labelled as provincials. This confirms that the Theban necropolis in these cases served as a burial spot for people from elsewhere. They are thus part of the assumed 5\% of external functionaries buried in Thebes (Assmann 2000, 318, Fn. 468; but see Fitzenreiter 1995, 115). Some of these New Kingdom mayors also represent a specific chronological phase in the history of the Theban necropolis, as Kn-Jmn R3k3 (Memphis), Dhw.tj (Nefrusi?), $M n t . w-h r-h p s=f$ (Qau El-Kebir), Jnj-jtj=f, Mnw (both Thinis) and Sn-nfrj (Koptos [or Letopolis?]) are datable to Hatshepsut and Thutmosis III. This was when Thebes first came to boast the New Kingdom elite necropolis with its nationwide gravitational appeal (Wohlfahrt 2005, 533).

The tombs we have just dealt with were sepulchres in capital city

from some of both his and his father's titles, as well as part of his biographical inscription in TT 99 (Strudwick 2000, 243-244). Whether Dhw.tj (TT 11: Porter and Moss 1985, 21-24; Davies and Macadam 1957, Nr. 257) was an actual mayor of Nefrusi is not certain, but Kessler 1981, 144-145 argues for his position there. 
necropoleis. However, elite tombs were also located in burial grounds far distant from the capital cities. These not only belonged to local administrative and religious staff such as mayors and local priests but also to administrators of the central government. Some possessed titles that connected them to local cults or offices, but their main functional titles clearly show that they once belonged to the elite of the court, (the 'Hofstaat' or 'Hofgesellschaft' in Raedler's terms [2006; 2012]), where they served and lived for the main part of their career. High-ranking military generals and officers can also be included in this category of the courtly elite. Leaving the urban cemeteries of New Kingdom Nubia and their prosopography aside (see e.g. Aniba [Steindorff 1935], Soleb [Schiff-Giorgini 1971], and Sai [MinaultGoult 1997]), such people can be found in provincial elite tombs in Nag' El-Bogga, Kom Ombo(?), Elkab, Er-Rizeiqat, El-Mashayikh, Awlad Azzaz, El-Khawaled, Deir Rifeh, Asyut, Tuna El-Gebel, Zawiet Sultan, Sedment, Heliopolis, Athribis, Bubastis and Tell El-Maskhuta, to name only the best known examples. ${ }^{4}$ In the majority of cases mentioned in this list, the most

4 This is a preliminary and incomplete list: jm.j-r'-pr-wr-n-pr-hmm.t-nsw Nht-Mnw (Dehmît/ Nag' El-Bogga, 20th Dynasty: Fakhry 1935; Herrmann 1936; Hofmann 2004, 115); wpw. tj-nsw-r-ḩ3s.t-nb.t wr-m-pr-nsw Nht-Mnw (Kom Ombo, Ramesside: Budka 2001, 243, Kat.-Nr. 257); jm.j-r'-htm.t J`h-ms P3-n-Nhb.t (Elkab Nr. 2, T. III.: Porter and Moss 1937, 176-177); jm.j-r'-pr-ḥd jm.j-r'-pr.wj-ḥd jm.j-r'-pr.wj-nbw \%bk-ms (Er-Rizeiqat, A. III.: Hayes 1939); jm.j-r'-pr sḩ3.w-nsw-m3 ${ }^{e}-n-n b-t 3 . w j ~ h r . j-s 3 . w t j-s \underline{h} 3 . w-n-n b-t 3 . w j ~ J j-m j-s b 3$ (El-Mashayikh, 19th Dynasty/Merenptah: Ockinga and Al-Masry 1990,33-60);jm.j-r'-mne.j

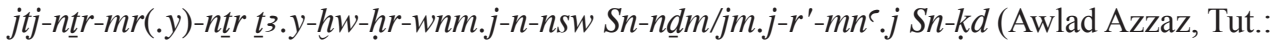

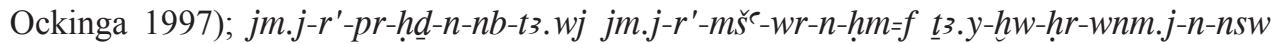
Swtj (El-Khawaled, S. I.-Ra.II.: Chaban 1901; Lefebvre 1908; Kamal el-Din 2010); jm.j-r'$m \check{s}^{e}$ jm.j-r'-ḩ3s.wt-rs.jt hr.j-pd.t hrrp-ḩ3s.wt-m-Hn.t-hnn-nfr s3-nsw Twtw (Deir Rifeh, NR: Griffith 1889, pls 16-18; Montet 1936, 144-152); jm.j-r'-web.w-n-Shm.t wr-swn.w shz.w$n s w-h r . j-t p$ Jmn-ḥtp (Asyut, Har.-S. I.: Karig 1969); jm.j-r'-šnw.tj S3-3s.t II and jm.j-r'$\check{s} n w . t j-n$-šm $. w-m h w$ S3-3s.t III (Asyut, Ra. II.: Satzinger 1978; Bohleke 1993, 324-341

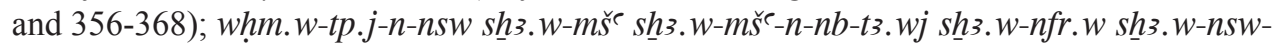
$m 3^{`}-m r . y=f S n w$ (Tuna El-Gebel, A. III: Bresciani 1981); jm.j- $r^{\prime}-j h . w-n-J m n-R{ }^{e} j m . j-r^{\prime}-j h . w-$ wr-n-Jmn-m-šme $. w-m h . w \quad j m . j-r^{\prime}-p r-w r \quad j m . j-r^{\prime}-s ̌ n w . t j-n-p r-J m n \quad j m . j-r^{\prime}-k 3 . t-n-n b-t 3 . w j$ sh3.w-nsw-n-nb-t3.wj Dhww.tj-ms (Tuna El-Gebel, 19th Dynasty: Daressy 1916); jm.j-r'-prwr-m-pr-nswjm.j-r'-pr-wr-n-nsw/nb-t3.wjjm.j-r'-šnw.tj-n.w/m-šm.w-mh.wshż.w-wdh.w-

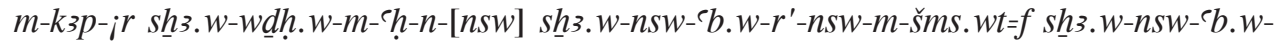
$r^{\prime}-n s w-m-{ }^{-} h-n-n s w s h 3 . w-n s w-m 3^{-}-m r=f N f r-s h r . w$ (Zawiet Sultan, early 19th Dynasty: Osing 1992);jm.j-r'-n'.t-tz.tj(P3-)Re-htp(Sedment, Ra.II.:Raue 1998; Raedler2004,354-375); hr.j-

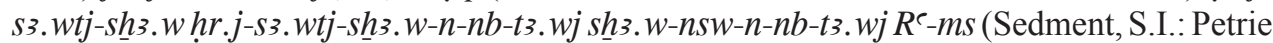
and Brunton 1924, 27, pls 77,1, 77,3-6); jm.j-r'-šms.w sḩ3.w-n-nb-t3.wj Hnm.w-m-ḩıb (Sedment, S.I.: Petrie and Brunton 1924, pl. 77, 9-10); jm.j-r'-mš -wr-n-nb-t3.wj jm.j-

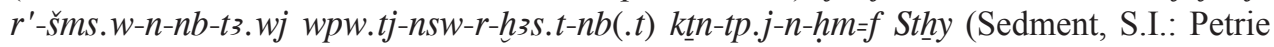
and Brunton 1924, 27, pls 69-70); jm.j-r'-ssm.t jdn.w-n-tj-n.t-ḥtr ḥr.j-pd्d.t kt n-tp.j-n-ḥm=f 
feasible explanation seems to be that these tombs were built in the elite necropoleis of the hometown of the official in question (cf. Herrmann 1936, 23; Hayes 1939, 24; Helck 1958, 540; Osing 1992, 35; Raue 1998, 350). Taking the spatial range of these tombs into account, it is remarkable that they are distributed all the way from Lower Nubia to the Delta. There are regional concentrations, but no area of the Nile valley or regions such as the Delta is left out.

\section{Tomb location: textual discourse}

Having listed some provincial elite necropoleis containing tombs belonging to members of the Hofstaat, their location can now be placed in context to reveal their territorial meaning. Certain textual statements of elite Egyptians commenting on the location of their tombs can be highlighted here. They come from tombs of the capital city necropoleis, but also seemingly in larger quantities from sepulchres located in provincial cemeteries. Keeping Jan Assmann's (2000, 229) characterisation of the Egyptian tomb as the 'essential focus of belonging' in mind, we can now add another remark of his, that Egyptians considered their place of birth to be the ideal spot for their tomb. This implies that a person's origin and provenance were expressed

P3-ḥm-ntr (Sedment, Ra. II.: Petrie and Brunton 1924, 27-28, pls 56,6, 68, 78,28-31); jm.j-r'$m \breve{s}-w r s h 3 . w-n s w H r j$ (Sedment, 19th Dynasty: Petrie and Brunton 1924, pls 48, 16-17, 58,46);

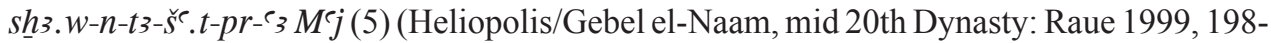
199); wb3.w $R^{e}-m s-s w-m-p r-R^{e}$ (1) (Heliopolis/Ain Schams, Ramesside: Raue 1999, 228); $w b 3 . w-n s w-w^{\bullet} b-\left\ulcorner. w j R^{e}-m s s / N h t-h r-K m . t\right.$ (1) (Heliopolis/Ain Schams, Ramesside: Raue 1999, 229); jm.j-r'-pr-wr-n-nb-t3.wj jm.j-r'-šnw.tj sḩ3.w-nsw Hej-m-W3s.t (1) (Heliopolis/

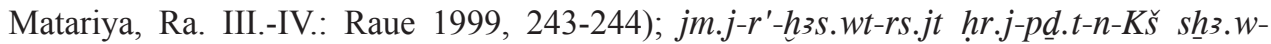
nsw ț.y-ȟw-hrr-wnm.j-n-nsw Pyjzy (Tell El-Yahudijeh/Shinbin El-Qanateer (Chobak), Ramesside: Daressy 1920); jm.j- $r^{\prime}-m \check{s}^{e} j m . j-r^{\prime}-m n f y . t \quad s \underline{h} 3 . w-n s w-m 3^{\top}-m r y=f \quad M n \underline{t} . w-m-$ t3.wj (Athribis, Ra. II. or. III.: Vernus 1978, doc. 58, 59); s3-nsw-n-Ǩ́ Hrj I (Bubastis,

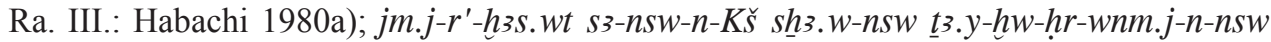
Hrj II (Bubastis, Ra. III.: Habachi 1980b); jm.j-r'-n'.t-tz.tj Jwtj (Bubastis, Ra. III. (?): Habachi and Ghalioungui 1971, 68-69; Moje, forthcoming a; Moje, forthcoming b); jm.j$r^{\prime}-{ }^{-}-h n w . t j-n-n b-t 3 . w j$ wb3.w-nsw-w'b-e.wj-(m-b3h-n-nb-t3.wj) wpw.tj-nsw-r-h $3 s . t$ wpw.tj-

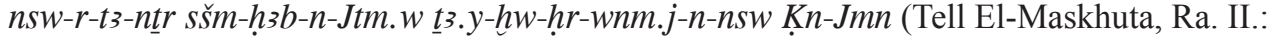
see the press releases http://www.drhawass.com/blog/press-release-new-tomb-discoveredismailia [status as of Feb. 26th, 2013] and http://news.discovery.com/history/tomb-of-kenamun-royal-court-official-unearthed-in-egypt.html [status as of Nov. 27th, 2012]. I would like to thank Sławomir Rzepka for photographs and information about this tomb, which was completely destroyed during the revolution at the beginning of 2011: see http://www. drhawass.com/blog/status-egyptian-antiquitiestoday-3-march-2011 [status as of Nov. 27th, 2012]). 
by the location of his tomb. A contrasting and opposing relationship was the person's proximity to the king or court administration, which could 'create even stronger affiliations, constitute an even stronger focus of identity.' (transl. by the author from Assmann 2000, 318, Fn. 468).

Coming back to the textual discourse and the categories of space that are of importance in this regard, in an offering formula of the 18th Dynasty to Ptah we read: 'May he (=Ptah) give, that the footsteps are at their (proper) place without fear of hearing evil until the achievement of the jmsh-status in peace in the Great West of his city like all the favoured ones' (Barta 1968, 120 , Bitte 114c). The expression 'his city' refers to the city of Ptah, the hometown of the individual, in whose western necropolis he wishes to be buried. The nexus between 'city', tomb and social memory is paradigmatically expressed in a passage on an early 19th Dynasty tomb stela from Saqqara of the Overseer of the Women's Quarters, Pth-ms (MMA 67.3), who is even designated to come from Memphis by a so-called 'Herkunftsvermerk' (cf. Auenmüller, forthcoming, 364-366). In line 13 we read in an adoration to the city god Ptah: 'May you grant that I rest $<$ in $>$ (my) Place of Eternity in the west of my city Hw.t-k3-Pth (=Memphis) and that I reach the fathers and forefathers who are (already) gone in peace' (Kamal 1905, 29-31; Mercer 1914, 177-178, Pl. 9; see also http://www.metmuseum.org/collections/ search-the-collections/100006154 [status as of Feb. 22nd, 2013]).

At the beginning of the 18th Dynasty, a certain Captain J`h-ms, Son of Ibana, comments upon the fact that he himself built his rock-cut tomb in the necropolis of Elkab in Upper Egypt: 'I became old, after reaching age. My favour was like the first of times, my popularity [was ...]. (Now) I [rest] in the rock-cut tomb, which I myself made (for me)' (Urk. 4.10.5-9). We find a comparable statement in an elite tomb chamber belonging to the treasurer Sbk-ms in Er-Rizeiqat under Amenhotep III, some 24km south of Thebes. In a prayer to the moon, he describes himself as follows: 'He has built his tomb, which he founded in thy province, this his tomb being in it' (Hayes 1939, pl. 5). In this context, William C. Hayes $(1939,24)$ observes that ' $[\mathrm{t}]$ here can be little doubt that Sobk-mose was a resident, if not a native, of his town. (...); and the fact that he built his tomb in this small out-ofthe-way place instead of at the capital city, Thebes, where he worked and spent much of his time, indicates that he must at least have resided in Sumenu (Er-Rizeiqat) long enough to regard it as his home'. In the text of a stela of the mayor of Kawa P3-nht in Upper Nubia from the time of Tut-ankhAmen, we find a prayer to [Amun, Re-Harakhte] and Atum, wherein P3-nht speaks about his wish to be endowed with life in 'his city', which is supposedly 
Kawa. Additionally, we read about his desire for 'a perfect interment after old age in the great western necropolis of his city in order to become jms $h$ ' in an offering formula (Macadam 1949, 1-3, pls 2-3). Although we do not yet know of a contemporaneous New Kingdom necropolis located in Kawa, M. F. Laming Macadam (1949, 3, Fn. 14) assumes that it has once existed in the environs of the city. In view of P3-nht' s role as the mayor of Kawa, it is very possible that Kawa was not only his place of office, but that it also could be his place of origin. On the contrary, he might also be one of the Egyptian officials which were sent to Kawa by Tutankhamen to administer his newly established city in Upper Nubia.

Advancing a little in time to the late 18th/early 19th Dynasty and moving to Zawiet Sultan, ancient Hebenu, in Middle Egypt, we find the rock-cut tomb of Nfr-shr.w, who was high steward of the king. During his tenure, he would presumably have lived and worked at the Memphite residence (Osing 1992, 35). Several texts in his tomb, which Nfr-shr.w calls 'my tomb in the midst of the Oryx nome' (Osing 1992, 46, pl. 35, col. 3) or 'my tomb in $H_{b n w '}$ ' Osing 1992, 75, pl. 44), explicitly concern its location in the necropolis itself under the prominent hilltop. They additionally refer to the role of the city god Horus of Hebenu in assigning this tomb to $\mathrm{Nfr}$ shr.w: 'Horus, the lord of Hebenu, the Great god in the Oryx nome, he may grant (me) to be buried in the mountain ridge of his city, to perfectly land in peace because of (my) jmsh-status on the day of the perfect burial, which he commands.' Nfr-shr.w elaborates on this as follows: 'May my tomb be firm in his city and my corpse within it, without my name perishing on it ever in the future.' Finally, he comments on the fact that he deliberately built his tomb there: 'I erected (my) cavern near his temple (...)' (all citations after Osing 1992, 62, pl. 39d). In these texts, the relationship between the city, the city god and the location of the tomb are portrayed in exemplary fashion, but the term 'city' is only used here to refer to the city of the local god Horus of Hebenu.

Moving back to Lower Nubia into the early 20th Dynasty, we encounter an elaborate rock-cut tomb at Nag' el-Bogga, now lost in the waters of Lake Nasser, of an jm.j-r'-pr-wr-n-pr-hm.t-nsw called Nht-Mnw (Hermann 1936). There are indications that Nht-mnw was connected to the temple of Re at Heliopolis and its festivals, since there is a standard-bearer statue of both him and his mother $M r=s-g r$ (now kept in Berlin, ÄM 4422) which was most likely erected in Heliopolis (Raue 1999, 221-223). In the context of his tomb decoration, we find a ritual scene in which the tomb owner is offered by a $h m-k 3$-priest. The priest addresses $N h t-M n w$ as follows: 
'You are in your tomb [of eternity?], which you built (for yourself) in your city and which was assigned by [your] lord [for you ...]' (Hermann, 1936, 12). By combining the contents of this passage with the tomb location, it becomes clear that Nht-mnw really returned to Lower Nubia for burial and that the tomb explicitly marks his place of origin.

\section{Conclusion}

There are more examples of such texts which could be quoted. However, it can already be seen that the location of a tomb of a member of the elite has to be understood in the context of Assmann's three pivotal terms: Heimat, Grab, Stadt (Assmann 2000, 229-238). Nevertheless, location currently only plays a small role in discourse concerning the Egyptian tomb and its meaning as a whole. The relationship of the tomb owner to the king, his social and functional roles, his integration into and prominence within his own personal surroundings, as well as the provision of offerings, the functioning of rituals and the safe passage through the liminal phases of death and burial have generated far more Egyptological interest. It therefore seems that location has overwhelmingly been considered an implicit discursive category when thinking about the significance of tombs. However, if we regard an Egyptian elite tomb as a monument for posterity that operated as a cult place regularly visited by priests and members of the family (especially during specific feasts and gods' festivals), we can see the necessity of having a location where all of these ritual and social demands could be met. For instance, if an elite member of the Theban or Memphite Hofstaat erected his tomb in a provincial setting and not in one of the capital city necropoleis, we may assume that his family and primal social ties were to be found in precisely this provincial milieu. Therefore, we can also postulate that the site of the tomb is of importance since it marks his geographical origin.

More research is perhaps needed on specific functional groups of the Egyptian elite to gain a clearer picture of how social status, administrative function and the choice or assignment of tomb locations are interrelated. However, it is clear that tomb location was subject to social scaling; the highest members of the administrative elite seem to have been buried in the capital city necropoleis, whilst the lower strata of the elite (in terms of functional rank and local duties) chose to be buried in cemeteries of their hometown or place of office. Whilst place of origin and office usually coincided in the lower elite milieu, this link, which Assmann describes as the cultural ideal (Assmann 2000, 229), was broken in the higher classes. 
These people either decided or obtained permission from the king to build their tombs in the elite necropoleis of Thebes, Amarna or Memphis, even if they did not originate or were not recruited from there. However, there are exceptions to this phenomenon, for example the monumental tomb of the Vizier (P3)-Re-htp at Sedment (see above Fn. 5). His case and others, such as the officials Sbk-ms, Nfr-shr.w and Nht-Mnw discussed above, demonstrate that the location of the tomb even if no text such as those previously discussed has been found really tells us something about the spatial relations of its owner in terms of geographic provenance.

Generally, a tension is always visible between the factors of hometown, family, place of office and proximity to the king. However, this is only the case at the highest levels of the administrative, religious and military elite. When asking who these people were and where they came from, we should therefore now take the location of their tomb into account with good reason. We can then ask what kind of relationship is marked by these funerary monuments. Is it geographic origin and social embeddedness, functional duties, proximity to the king or two or all three of these aspects combined? These were the ideological considerations determining the site of erection of an elite tomb. They portray the key elements in the territoriality of the Egyptian elite of the New Kingdom in terms of the elite's spatial identity and behaviour. In any case, the tomb is significant in that it signifies the spatial relationship between the owner and the location where it was built. Even if the tomb does not mark the place of origin of its owner and thus does not follow the supposed Egyptian 'ideal', it still constitutes a culturally meaningful and consciously claimed territorial relation of his to space and place.

\section{References}

Agnew J. 2005. Sovereignty regimes: territoriality and state authority in contemporary world politics. Annals of the Association of American Geographers 95, 437-461.

Albert M. 2001. Territoriality and Modernization. Retrieved from www.unibielefeld.de/soz/iw/pdf/albert_3.pdf (status as of Feb. 19th, 2013).

Altman I. 1975. The Environment and Social Behaviour: Privacy, Personal Space, Territory and Crowding. Monterey. 
Arp J. 2012. Die Nekropole als Figuration. Zur Methodik der sozialen Interpretation der Felsfassadengräber von Amarna. (Göttinger Orientforschungen: Ägypten 4/50). Wiesbaden.

Assmann J. 2000. Herrschaft und Heil. Politische Theologie in Altägypten, Israel und Europa. Munich.

Auenmüller J. 2011. Individuum - Gruppe - Gesellschaft - Raum: Raumsoziologische Perspektivierungen einiger (provinzieller) ḩ.tj-eBürgermeister des Neuen Reiches. In G. Neunert, K. Gabler and A. Verbovsek (eds), Sozialisationen: Individuum - Gruppe - Gesellschaft. Beiträge des ersten Münchner Arbeitskreises Junge Ägyptologie (MAJA 1), 17-33. (Göttinger Orientforschungen: Ägypten 4/51). Wiesbaden.

Auenmüller J., forthcoming. Die Territorialität der Ägyptischen Elite(n) des Neuen Reiches - Eine Studie zu Raum und räumlichen Relationen im textlichen Diskurs, anhand der prosopografischen Dokumentation und im archäologischen Record. PhD thesis, Freien Universität Berlin, 2013.

Barta W. 1968. Aufbau und Bedeutung der altägyptischen Opferformel. (ÄgForsch 24). Glückstadt.

Binder S. 2008. The Gold of Honour in New Kingdom Egypt. (Australian Centre for Egyptology, Studies 8). Oxford.

Björkmann G. 1974. Neby, the Mayor of Tjaru in the Reign of Tuthmosis IV. JARCE 11, 43-51.

Bohleke B. 1993. The Overseers of Double Granaries of Upper and Lower Egypt in the Egyptian New Kingdom, 1570-1085 B.C. Ann Arbor.

Bresciani E. 1981. La stele Cat. 1908 del Museo Civico die Bologna e gli altri monumenti del primo araldo del re, scriba del re, scriba dell'esercito e scriba delle reclute, Senu. MDAIK 37, 85-95.

Budka J. 2001. Der König an der Haustür. Die Rolle des ägyptischen Herrschers an dekorierten Türgewänden von Beamten im Neuen Reich. (Veröffentlichungen der Institute für Afrikanistik und Ägyptologie der Universität Wien 94 = Beiträge zur Ägyptologie 19). Vienna.

Burt W. H. 1943. Territoriality and home range concepts as applied to mammals. Journal of Mammalogy 24, 346-352.

Carpenter C. R. 1961. Territoriality. A review of concepts and problems. In A. Roe and G. G. Simpson (eds), Behaviour and Evolution, 224-250. New Haven.

Cashdan E. 1983. Territoriality among human foragers: ecological models and an application to four bushman groups. CurrAnthr 24/1, 47-66. 
Châban M. M. E. 1901. Un tombeau de la XIXe dynastie à El-Khawaled. ASAE 2, 137-140.

CRE 13, Abstracts. Retrieved from http://de.scribd.com/doc/122179597/ CRE-XIII-Abstracts-pdf (status as of Feb. 22nd, 2013).

Daressy G. 1916. Un sarcophage de Tounah. ASAE 16, 115-120.

Daressy G. 1920. Un groupe de statues de Tell El Yahoudieh. ASAE 20, 161-165.

Davies N. D. G. 1903-1908. The Rock Tombs of El Amarna. Part 1-6. (ASE 13-18). London.

Davies N. D. G. 1913. Five Theban Tombs (being those of Men tuherkhepeshef, User, Daga, Nehemawäy and Tati. (ASE 21). London.

Davies N. D. G. and Macadam M. F. L. 1957. A Corpus of Inscribed Egyptian Funerary Cones. Oxford.

Dijk J. van 1988. The development of the Memphite Necropolis in the Post-Amarna period. In A.-P. Zivie (ed.), Memphis et ses Nécropoles au Nouvel Empire, 37-46. Paris.

Dodson A. and Ikram S. 2008. The Tomb in Ancient Egypt. Royal and Private Sepulchres from the Early Dynastic Period to the Romans. London.

Dyson-Hudson R. and Smith E. A. 1978. Human territoriality: an ecological reassessment. American Anthropologist. New Series. 80, 21-41.

Dziobek E. and Abdel Raziq M. 1990. Das Grab des Sobekhotep, Theben Nr. 63. (AV 71). Mainz.

Engelmann-von Carnap B. 1995. Soziale Stellung und Grabanlage. Zur Struktur des Friedhofs der ersten Hälfte der 18. Dyn. in Scheich Abd el-Qurna und Chocha. In J. Assmann, E. Dziobek, H. Guksch and F. Kampp (eds), Thebanische Beamtennekropolen. Neue Perspektiven archäologischer Forschung. Internationales Symposion Heidelberg 9.-13.6. 1993, 107-128. (Studien zur Archäologie und Geschichte Altägyptens 12). Heidelberg.

Engelmann-von Carnap B. 1999. Die Struktur des Thebanischen Beamtenfriedhofs in der ersten Hälfte der 18. Dynastie. Analyse von Position, Grundrißgestaltung und Bildprogramm der Gräber. (AV 15). Berlin.

Fábián Z. I. 1997. Preliminary report on the first two seasons in Theban Tomb 184 (Nefermenu). SAK 24, 81-102.

Fábián Z. I. 2005. Nefermenu (TT 184), April 2003. ASAE 79, 41-59.

Fischer H. G. 1954. Four provincial administrators at the Memphite cemeteries. JAOS 74/1, 26-34. 
Fakhry A. 1935. The tomb of Nakht-Min at Dehmît. ASAE 35, 52-61.

Fitzenreiter M. 1995. Totenverehrung und soziale Repräsentation im thebanischen Beamtengrab der 18. Dynastie. SAK 22, 95-130.

Forsberg T. 1996. Beyond sovereignty, within territoriality: mapping the space of late-modern (geo)politics. Cooperation and Conflict 31, 355-386.

Franke D. 1991. The career of Khnumhotep III of Beni Hassan and the so-called decline of the normarchs. In St. Quirke (ed), Middle Kingdom Studies, 51-67. New Malden.

Geßler-Löhr B. 1997. Bemerkungen zur Nekropole des Neuen Reiches von Saqqara vor der Amarnazeit 2: Gräber der Bürgermeister von Memphis. OMRO 77, 31-71.

Gifford R. 1997. Environmental Psychology. Principles and Practice. Boston.

Grajetzki W. 2003. Burial Customs in Ancient Egypt. Life in Death for Rich and Poor. London.

Grajetzki W. 2009. Court Officials of the Egyptian Middle Kingdom. London.

Griffith F. L. 1889. The Inscriptions of Siût and Dêr Rîfeh. London.

Guksch H. 1994. Königsdienst. Zur Selbstdarstellung der Beamten in der 18. Dynastie. (Studien zur Archäologie und Geschichte Altägyptens 11). Heidelberg.

Habachi L. 1980a. S.v. Hori II. In $L \ddot{A} 3,1-2$.

Habachi L. 1980b. S.v. Hori III. In $L \ddot{A} 3,2-3$.

Habachi L. and Ghalioungui P. 1971. The 'House of Life' of Bubastis. ChrÉg 46, 59-71.

Hayes W. C. 1939. The Burial Chamber of the Treasurer Sobk-Mose from Er Rizeikat. (The Metropolitan Museum of Art Papers 9). New York.

Helck W. 1958. Zur Verwaltung des Mittleren und Neuen Reichs. (PÄ 3). Leiden.

Hermann A. 1936. Das Grab eines Nachtmin in Unternubien. MDAIK 6, $1-40$.

Hoffmann M. A. 1980. Egypt before the Pharaohs. The Prehistoric Foundations of Egyptian Civilization. London.

Hofmann E. 2004. Bilder im Wandel. Die Kunst der Ramessidischen Privatgräber. (Theben 17). Mainz.

Jüngst P. 2000. Territorialität und Psychodynamik. Eine Einführung in die Psychogeographie. Gießen. 
Kákosy L., Bács T. A., Bartos Z., Fábián Z. I. and Gaál E. 2004. The Mortuary Monument of Djehutimes (TT 32). (StudAeg Series Major 1). Budapest.

Kamal A. B. 1905. Sur une stèle aujourd'hui perdue. RecTrav 27, 29-31.

Kamal El-Din N. 2010. Ein Sarg des Schatzhausmeisters Suti. MDAIK 66, 131-142.

Kanawati N. 2004. The interrelation of the capital and the provinces in the Sixth Dynasty. Bulletin of the Australian Centre for Egyptology $15,51-62$.

Karig J. S. 1969. Die Kultkammer des Amenhotep aus Deir Durunka. ZÄS 95, 27-34.

Kessler D. 1981. Historische Topographie der Region zwischen Mallawi und Samalut. (Tübinger Atlas des Vorderen Orient Beihefte, Serie B 30). Wiesbaden.

Kitchen K. A. 1979. Ramesside Inscriptions 2. Historical and Biographical. Oxford.

Kitchen K. A. 1980. Ramesside Inscriptions 3. Historical and Biographical. Oxford.

Kitchen K. A. 1982. Ramesside Inscriptions 4. Historical and Biographical. Oxford.

Klauser F. R. 2008. Rethinking the relationships between society and space: a review of Claude Raffestin's conceptualisation of human territoriality. (Working Paper No 37, Social Sciences Research Centre, National University of Galway). Retrived from www.nuigalway.ie/ research/ssrc/documents/territoriality_working_paper_francisco_ klauser.pdf (status as of Feb. 10th, 2013).

Klauser F. R. (ed.) 2010. Claude Raffestin - Zu einer Geographie der Territorialität. Stuttgart.

Kruck E. 2012. Dra'Abu El-Naga 1. Eindrücke: Grabkegel als Elemente thebanischer Grabarchitektur. (AV124). Wiesbaden.

Lefebvre M. G. 1908. Notes sur Khawaled, ASAE 9, 158-161.

Lupo S. 2007a. Territorial appropriation during the Old Kingdom (XXVIIIth-XXIIIrd centuries BC): The royal necropolises and the pyramid towns in Egypt. (BAR-IS 1595). Oxford.

Lupo S. 2007b. Territory and territoriality in ancient Egypt. An alternative interpretation for the Early Dynastic and Old Kingdom periods. GM 214, 71-83.

Lyman S. M. and Scott M. B. 1967. Territoriality: a neglected sociological dimension. Social Problems 15, 236-249. 
Macadam M. F. L. 1949. The Temples of Kawa I. The Inscriptions. London.

Malmberg T. 1980. Human Territoriality. Survey of Behavioral Territories in Man with Preliminary Analysis and Discussion of Meaning. New Babylon. (Studies in the Social Sciences 33). The Hague.

Manniche L. 1988. Lost Tombs. A Study of Certain Eighteenth Dynasty Monuments in the Theban Necropolis. (Studies in Egyptology). London.

Martin R. D. 1972. Concepts of human territoriality. In P. J. Ucko, R. Tringham and G. W. Dimbleby (eds), Man, settlement and urbanism, 427-446. London.

Martin G. T. 2000. Memphis: the status of a residence city in the Eighteenth Dynasty. In M. Bárta and J. Krejcí (eds), Abusir and Saqqara in the Year 2000, 99-120. Prague.

Minault-Goult A. 1997. La nécropole pharaonique de Sai. Cahier de Recherche de l'Institute de Papyrologie et d Egyptologie de Lille 17/2, 99-104.

Moje J., forthcoming a. Cat.-No. 27. In M. I. Bakr and H Brandl (eds), Egyptian Antiquities from Bubastis, Tanis, and other Sites in the Eastern Delta. (Museen im Nildelta 2). Berlin.

Moje J., forthcoming b. Inscr.-No. H-739 und H-754. In M. I. Bakr and $\mathrm{H}$ Brandl (eds), Egyptian Antiquities from the Eastern Nile Delta: The Inscriptions. (Museen im Nildelta 3). Berlin.

Montet P. 1936. Les tombeaux de Siout et de Deir Rifeh (troisième article). Kêmi 6, 131-163.

Morris E. F. 2005. The Architecture of Imperialism: Military Bases and the Evolution of Foreign Policy in Egypt's New Kingdom. (P̈̈ 22). Leiden.

Newberry P. E. 1957. Funerary Statuettes and Model Sarcophagi. Nos. 46530-48575. (CG). Cairo.

Ockinga B. and Al-Masri Y. 1988 and 1990. Two Ramesside Tombs at El-Mashayikh. Part 1: The Tomb of Anhurmose - the Outer Room. Part 2: The Tomb of Anhurmose - The Inner Room and The Tomb of Imiseba. Sydney.

Ockinga B. 1997. A Tomb from the Reign of Tutankhamun at Akhmim. (Australian Centre for Egyptology, Reports 10). Warminster.

Osing J. 1992. Das Grab des Nefersecheru in Zawyet Sultan. (AV 88). Mainz.

Petrie W. M. F. and Brunton G. 1924. Sedment 2. (BSAE 35). London. 
Porter B. and Moss R. L. B. 1937. Topographical Bibliography of Ancient Egyptian Hieroglyphic Texts, Reliefs, and Paintings 5. Oxford.

Porter B. and Moss R. L. B. 1985. Topographical Bibliography of Ancient Egyptian Hieroglyphic Texts, Reliefs, and Paintings 12/1. Oxford.

Raedler C. 2003. Zur Repräsentation und Verwirklichung pharaonischer Macht in Nubien: Der Vizekönig Setau. In R. Gundlach and U. Rössler-Köhler (eds), Das Königtum der Ramessidenzeit. Voraussetzungen - Verwirklichung - Vermächtnis. Akten des 3. Symposiums zur ägyptischen Königsideologie in Bonn 7.-9. 6. 2001, 129-173. (Ägypten und Altes Testament 36/3). Wiesbaden.

Raedler C. 2004. Die Wesire Ramses' II. - Netzwerke der Macht. In R. Gundlach and A. Klug (eds), Das ägyptische Königtum im Spannungsfeld zwischen Innen- und Außenpolitik im 2. Jahrtausend v. Chr. 1, 277-416. (Königtum, Staat und Gesellschaft 1). Wiesbaden.

Raedler C. 2006. Zur Struktur der Hofgesellschaft Ramses' II. In R. Gundlach and A. Klug (eds), Der ägyptische Hof im Neuen Reich, 39-88. (Königtum, Staat und Gesellschaft 2). Wiesbaden.

Raedler C. 2012. 'Kopf der Schenut' - politische Entscheidungsträger der Ära Ramses' II. In H. Beinlich (ed.), 'Die Männer hinter dem König.' 6. Symposium zur ägyptischen Königsideologie, 123-150. (Königtum, Staat und Gesellschaft 4/3). Wiesbaden.

Raffestin C. 1984. Territoriality: a reflection on the discrepancies between the organization of space and individual liberty. International Political Science Review 5, 139-146.

Raue D. 1988. Ein Wesir Ramses' II. In H. Guksch and D. Polz (eds), Stationen. Beiträge zur Kulturgeschichte Ägyptens. Fs. Stadelmann, 341-351. Mainz.

Raue D. 1999. Heliopolis und das Haus des Re. Eine Prosopographie und ein Toponym im Neuen Reich. (AV 16). Berlin.

Raven M. J. 2000. Twenty-five years of work in the New Kingdom necropolis of Saqqara: looking for structure. In M. Bárta and J. Krejcí (eds), Abusir and Saqqara in the Year 2000, 133-144. Prague.

Richards J. 2005. Society and Death in Ancient Egypt. Mortuary Landscapes of the Middle Kingdom. Cambridge.

Sack R. D. 1983. Human territoriality: a theory. Annals of the Association of American Geographers 74/1, 55-75.

Sack R. D. 1986. Human Territoriality: Its Theory and History. (Cambridge Studies in Historical Geography 7). Cambridge. 
Säve-Söderbergh T. 1957. Four Eighteenth Dynasty Tombs. (Private Tombs at Thebes 1). Oxford.

Satzinger H. 1978. Der Leiter des Speicherwesens Si-Êse Sohn des Qenj und seine Wiener Statue. JKSW 74, 7-28.

Scheflen A. E. and Ashcraft N. 1976. Human Territories: How We Behave in Space-Time. Englewood Cliffs N.J.

Schiff-Giorgini M. 1971. Soleb 2. Les Nécropoles. Florence.

Schneider H. D. 1977. Shabtis 1 und 2. An introduction to the History of Ancient Egyptian Funerary Statuettes with a Catalogue of the Collection of Shabtis in the National Museum of Antiquities at Leiden. Leiden.

Seidlmayer S. 1999. New rock inscriptions at Elephantine. EA 14, 41-43.

Seidlmayer S. 2003. New Rock Inscriptions on Elephantine Island. In Z. Hawass and L. Pinch-Brock (eds), Egyptology at the Dawn of the Twenty-first Century, vol. 1, 440-447. Cairo.

Siclen III C. C. van 1981. Wall Scenes from the Tomb of Amenhotep (Huy) Governour of Bahria Oasis. San Antonio.

Steindorff G. 1935. Aniba 1-2. Mission archéologique de Nubie, 19291934. Glückstadt.

Strudwick N. 2000. The Theban Tomb of Senneferi: an overview of work undertaken from 1992 to 1999. Memnonia 11, 241-266.

Vernus P. 1978. Athribis. Textes et Documents relatifs à la Géographie, aux Cultes, et à l'Histoire d'une Ville du Delta égyptien à l'Époque Pharaonique. (BdE 74). Cairo.

Vollaard H. 2009. The logic of political territoriality. Geopolitics 14/4, 608-706.

Wada K. 2007. Provincial society and cemetery organisation in the New Kingdom. SAK 36, 347-389.

Wohlfarth S. 2005. Grabbeigaben im Flachbild der Privatgräber des Neuen Reiches - Versuch einer ikonographischen und kompositionellen Bestimmung. (Digitale Hochschulschriften der LMU München: http://edoc.ub.uni-muenchen.de/3188/). Munich.

Johannes Stefan G. Auenmüller Egyptology Seminar, Free University of Berlin Egyptological Institute with the Egyptian Museum,

University of Bonn johannes_auenmueller@yahoo.de 